\section{A desterritorialização da violência}

The deterritorrialization of violence

\section{João Trajano Sento-Sé2}

Lidas de um canto longínquo da periferia do mundo contemporâneo, as proposições de Wieviorka sobre a violência soam como saudável provocação para enfrentarmos o desafio de conferir inteligibilidade a um mundo que parece dinamitar todas as formas convencionais de produção de sentido. Não tenho a ambição de comentar cada um dos vários pontos levantados pelo autor. O que farei é reagir com uma ou outra proposição à leitura de seu artigo. Procurarei fazê-lo com certo cuidado já que, como é sabido, as questões enfrentadas por franceses, quando o assunto é violência, diferem muito daquelas com que lidamos nas grandes cidades brasileiras. Ainda assim acredito que há muito a se ganhar com um diálogo como esse, aqui sugerido.

Primeiro ponto: Wieviorka se reporta à hipótese formulada em seu livro Sociétés et terrorisme, segundo a qual a violência tomaria lugar em situações nas quais não dispomos de canais para o confronto organizado de interesses, idéias, visões de mundo. No lugar do conflito temos, então, a violência. $\mathrm{O}$ ponto é bom, sólido e se inscreve em uma longa e consistente tradição da sociologia. Gostaria, no entanto, de recolocá-lo de uma forma um pouco diversa.

Quando falamos da ameaça do terrorismo, do tráfico de armas, dos conflitos interétnicos, das guerras do tráfico de drogas e das gangues de rua de Los Angeles ou da Cidade do Cabo estamos, na verdade, falando de dinâmicas muito diversas entre si. O que, a meus olhos, elas têm em comum é evidenciarem não propriamente a ausência de canais organizados de conflito, mas da depreciação de mecanismos clássicos de controle social. Creio que é esse o pano de fundo dos variados fenômenos a que, hoje, chamamos de violência.

Tal como apresentado por Wieviorka, os tempos da Guerra Fria, da pujança sindical e de outras formas clássicas de organização coletiva parecem bem menos aterradores, se confrontados com a aparente anarquia em que vivemos hoje. Wieviorka lembra das guerras das antigas colônias e das ditaduras do Terceiro Mundo, cuja capacidade de produção de violência possivelmente jamais terá

\footnotetext{
${ }^{2}$ Departamento de Ciências Sociais, Uerj. joaotra-
} jano@uol.com.br quantificação precisa, como manifestações terríveis, mas secundárias num mundo que, de um modo ou de outro, era razoavelmente organizado. Pois bem, proponho que esse mundo que se desfez diferia em dois aspectos de nossa problemática contemporaneidade.

Em primeiro lugar, os mecanismos políticos, policiais, culturais e simbólicos de controle funcionavam de tal modo que havia, de fato, taxas mais elevadas de tranqüilidade para certos segmentos da população mundial. A classe operária do mundo industrial desfrutava de relativa prosperidade, as classes abastadas, mesmo dos países pobres, podiam dormir tranqüilas, uma vez que a violência estava isolada nos confins da África, nas selvas do Vietnã, ou nos porões das ditaduras da América Latina. A violência existia, mas não era um problema. O que a torna um problema, não somente político ou social, mas, também, sociológico? Enuncio, uma vez mais, minha própria proposição: os mecanismos que cimentavam o cordão sanitário, isolando a violência, se desfizeram; os mecanismos de controle social já não se têm mostrado eficazes. A violência se desterritorializou. Conseqüentemente, a vitimização potencial se alargou.

Não se trata de negar as mudanças ocorridas na natureza dos fenômenos marcados pela violência. Tampouco deixar de reconhecer que, em certas regiões e circunstâncias, tais manifestações se tornaram mais numerosas e com maior poder de violação. No entanto, creio que é necessário acrescentar que o transbordamento de seu raio de alcance para além de fronteiras antes relativamente eficazes tem um peso muito maior do que costumamos admitir. Esse é o fator mais relevante para pensarmos as alterações nas percepções de insegurança, a que Wieviorka faz menção na abertura de seu texto. Vivemos como se estivéssemos prestes a engrossar os índices de vitimização de alguma modalidade aterradora da violência que nos parece fora de controle.

Quando me refiro a mecanismos de controle social tenho em mente, é claro, as instituições do Estado, mas não somente. Reporto-me, também, a uma série de mecanismos psicológicos, culturais, simbólicos e sociais que não caberiam num quadro explicativo exclusivamente montado sobre a propalada, acertadamente, crise do Estado. Insisto nesse ponto porque intuo entre pesquisadores que lidam com o fenômeno da violência uma espécie de pudor em admitir que o que tínhamos e deixamos de ter são recursos eficazes de controle social. Tal resistência talvez advenha de uma certa associação entre a ênfase 
no controle social e a defesa de políticas discricionárias e conservadoras. Essa, porém, não é uma associação necessária.

Creio que, em vários aspectos, os mecanismos de controle social do período anterior ao que vivemos era despótico, autoritário e discricionário. Sua relativa eficácia não deve ser confundida com provável compatibilidade a padrões básicos de justiça no que tange aos direitos humanos e aos direitos dos povos. Há, portanto, ao menos em princípio, alguma positividade em ver tais mecanismos ruírem. O que se impõe, como Wieviorka assinala muito bem, é a criação de uma nova linguagem que sirva de conteúdo para uma gramática institucional que nos reconcilie com princípios a que damos importância. É a nostalgia da ordem antiga materializada no uso de uma linguagem anacrônica que alimenta os discursos e propostas despóticas, não propriamente o reconhecimento da importância de mecanismos de controle.

O mundo que se desfez era aterrador e insuportável para milhões que dele foram vítimas. Ocorre que os padrões com que lidamos com essa parcela da população se alteraram. É desejável seguir tentando convencer um árabe, hoje, da inferioridade de sua cultura diante da civilização das luzes (na verdade, trata-se de uma tentativa que vai de encontro a um razoável conhecimento histórico)? Podemos, ainda, encarar o homossexualismo como uma doença orgânica ou de caráter? Em um sentido um pouco diverso, é conveniente tentar dizer a um jovem negro de uma favela do Rio de Janeiro que o acesso a todos os signos de reconhecimento lhe estão irremediavelmente obstruídos, mas que, ainda assim, ele deve andar na linha? Não creio possível, nem desejável. Como, então, lidar com tais impossibilidades?

É a incapacidade de responder às perguntas mencionadas que revela nosso desamparo atual. Respostas disponíveis atualmente revelam uma indisfarçável incapacidade de aceitar e entender personagens até então insulados em cordões sanitários. Manifestam-se em propostas discricionárias, fóbicas, que negam ao outro o direito de estar no mundo a seu modo. Mesmo proposições marcadas por princípios pretensamente humanistas soam, muitas vezes, cínicas ou, na melhor das hipóteses, ingênuas e simplistas. Por vezes, subestimam avanços valiosos. Por exemplo: o processo que leva à ampliação das vítimas potenciais é contemporâneo de um outro em que antigos objetos de controle passam a ser reconhecidos como vítimas das antigas agências de controle que já não funcionam mais. Esse é o caso, por exemplo, das populações afro-ameri- canas nos estados do sul dos EUA, cujos direitos eram violados sob o amparo da lei. O mesmo vale para os homossexuais masculinos, nos tempos em que a sodomia era crime passível de punição judicial e escárnio social. Tais mudanças indicam que não somos somente trevas.

Vivemos tempos difíceis, mas presenciamos avanços e, a partir da desordem atual, podemos obter ganhos no que tange à ampliação do acesso a direitos e adoção de princípios básicos de eqüidade nas relações entre homens e povos. Para isso seria desejável nos empenharmos na busca por uma nova linguagem, tal como sugerido por Wieviorka, e evitar o pudor em reconhecer que a criação de mecanismos de ordenação social é um imperativo. Sem isso, corremos o risco de seguir assistindo o medo, que se generaliza, se converter em acirramento de ódios que, por sua vez, funcionam como combustível para a perpetuação, ainda que degradada, de mecanismos intoleráveis de controle e ordenação sociais. 